\title{
Media in the New Democracies of Postcommunist Eastern Europe
}

Growing up in Bulgaria during the 'transition' years, as a then 15-year old, I spent the summer of 1990 queuing up at the neighbourhood newsstand waiting for the daily delivery of freshly printed newspapers. Shortages of goods, including food and gasoline, caused long lines in front of many stores but the crowd waiting at the kiosk was eager to read about the latest political developments, and especially popular were the newspapers published by the newly established opposition parties. While there was no scarcity of political news via television and radio, there was always something special about the print media, much of which, including entertainment weeklies, were such a novelty. Twenty or so years later, I spent another summer among newspapers, in the archives of the National Library in Sofia, pouring through the pages and-with no digitalization of archives - collecting photographs of news articles published before each of the national legislative elections since 1990. Much has changed in the media environment since then, yet, the study of media in postcommunist societies and especially its relations to voters, parties, and politics in general is still in its infancy.

The relationship between media and democratic societies is extremely complex and multifaceted, with media performing several functions - dissemination of information, fact-checking, and accountability 'watchdog' (to name a few) - that are of importance for both new and established democracies. ${ }^{1}$ Yet, the role of media in a democracy depends greatly on the extent to which the former, and journalists who work in news outlets, are free from government and other influences, and can offer independent, critical, and diverse perspectives. Moving beyond such normative assertions, this paper discusses three aspects of media freedom - legal protections, ownership, and content - in the eleven postcommunist countries that are now member states of the European Union (EU) - Bulgaria, Croatia, Czech Republic, Estonia, Hungary, Latvia, Lithuania, Poland, Romania, Slovakia, and Slovenia. ${ }^{2}$ As part of this discussion, the paper provides a snapshot of the limited political communication research on the region that focuses on links between media and political outcomes. The paper also 
draws preliminary conclusions about the role of communist legacies in explaining the diversity of media freedom across this set of countries, and it concludes with a proposed research agenda for postcommunist media studies.

\section{Media Freedom and Plurality across the Postcommunist Countries}

Evaluation of legal provisions

Several organizations such as Freedom House (FH), Reporters Without Borders (RWB), and the International Research and Exchanges Board (IREX) evaluate the legal, political, and economic environment in countries across the world, as well as media practices and relations between government and media to present a broad picture of the presence of free and independent media in each country. ${ }^{3}$ Figure 1 graphs the FH Freedom of the Press scores between 1993-2013 for the EU EE countries compared to other European and postcommunist countries, and Table 1 provides the EU EE individual country rankings based on FH, Nations in Transit and RWB reports, compares them to regional averages, and provides a summary of trends since $2010 .{ }^{4}$

FIGURE ONE ABOUT HERE

\section{TABLE ONE ABOUT HERE}

Across all three indicators, the EU EE countries significantly outperform the postSoviet and the Western Balkan countries, with the former region having an overall ranking of 'free', although barely. The EU EE region also fares worse than the rest of the European Union in terms of media freedom. Yet, such generalizations are deceiving as they hide the diversity within both the EU EE and the EU 17 groups. Media freedom in southern European countries (EU SE) is at the same level as the EU EE, and in fact the indicators for Greece (not shown in the table but available in the annual reports) are 
worse than those of Bulgaria or Romania. On the other hand, the media environment in Estonia has the same level of freedom from government influence as those in the more established democracies in EU WE. In fact, in the RWB indicators, Czech Republic, Estonia, Slovakia, and Poland outperform the EU WE averages, and EU SE as a region trails the EU EE regional averages. Another trend that stands out is that level of media freedom experienced a decline since 2010 in a number of countries, including the EU SE and the Western Balkans. In the EU EE countries, the most serious deteriorations of press freedom and independence of media are seen in Bulgaria and Hungary.

\section{Trends in media ownership}

The scores and ranking presented above reflect evaluations of the legal media environment in each country as well as experts' views on recent developments that are seen as undermining media freedom and quality. While there is a variety of possible explanations of why media freedom is low and has declined in a number of EU EE countries, the section below focuses on one factor - ownership of media outlets. Who owns the media in each country and the extent to which ownership is concentrated in the hands of a few individuals or companies affects the diversity of news sources directly, the journalistic culture in media outlets, and potentially the extent and type of news coverage. Considering the strong evidence worldwide that private media ownership is related to greater levels of media freedom, ${ }^{5}$ and that it promotes political knowledge and activism, ${ }^{6}$ the section below provides a summary of the major media owners across the EU EE, followed by a discussion of the limited research on how ownership relates to media freedom. 
Despite the liberalization of the media markets in the early years of postcommunist transition, and the rapid proliferation of media outlets, the media environment in many postcommunist countries is highly concentrated in the hands of a few private companies. In many countries ownership transparency is very low, and the complex ties among major international conglomerates, their offshore subsidiaries, and local proxies make it difficult to know with certainty who owns what in the postcommunist media markets, Yet, based on reports by Media and Democracy in Central and Eastern Europe project and European Federation of Journalists, several conclusions stand out. ${ }^{7}$

In a majority of postcommunist countries, the predominant media companies are (were) foreign - based in the US or Western Europe. For example, the German-Swiss Ringier Axel Springer and the German Westdeutsche Allgemeine Zeitung (WAZ) have significant presence in the print media markets in the Czech Republic, Hungary, Poland, and Slovakia, and $W A Z$ dominated the markets in Bulgaria and Romania until 2010. In the Czech Republic these two companies own media outlets with $85 \%$ of the national print circulation, ${ }^{8}$ and another German company - Passauer Verlagsgruppe - has a monopoly over the regional print media in the country. Print media markets in the three Baltic states are characterized by the strong presence of Scandinavian companies, such as the Swedish Bonnier and the Norwegian Schibsted, although Estonia also has a strong domestic publishing company. Estonia is also exceptional for its high ownership transparency and fewer problems with threats and harassment of journalists. Slovenia is perhaps the only EU EE country where the strong presence of foreign media companies 
(Austrian, Belgian, and Swedish) has not resulted in their near monopoly of the print media sector.

The broadcast media market is also dominated by international companies; in the 1990s and 2000s US-based News Corporation had a strong presence in the region, owning the major private broadcasters in Bulgaria, Latvia, and Romania but it has recently withdrawn from these countries. Another US investment company (registered in Bermuda), Central European Media Enterprises (CEM) remains (or has replaced News Corporation) as the majority owner of private TV channels in Bulgaria, the Czech Republic, Romania, Slovakia, and Slovenia. The Swedish Modern Times Group (MTG) and Bonniers, and the Norwegian Schibsted have strong presences in Estonia, Latvia, Lithuania, and MTG also own TV channels in Bulgaria, the Czech Republic, and Slovenia.

Poland is a relative exception to the trend of foreign broadcaster dominance in the region. The two main commercial TV channels in the country are owned by local businessmen, and Poland also has a strong tradition of samizdat literature, leading for example to the emergence of the largest daily Gazeta Wyborcza. Agora, the owner of Gazeta and TVN is a joint-stock company, funded initially with an investment from the US-based Cox Media Group, and often credited for maintaining a tradition of investigative journalism, and editorial independence. ${ }^{9}$ However, when in 2014 the Polish government purchased $17.5 \%$ of the company's shares, and it now contributes heavily to Gazeta's advertising revenues, this raised concerns about the newspaper's impartiality in its reporting. ${ }^{10}$ 
Foreign companies entered the postcommunist media markets in the early 1990s and have established a durable presence in the region, yet several countries have experienced a reversal, with national owners exerting a growing importance. While on the surface of it, shifting ownership of media from foreign to local hands could be seen a positive development, as a sign that national markets are improving, and of fostering local business talent, understanding the consequences of this shift raises concerns about freedom of the press and independence of media in these countries. Three examples stand out in this respect; WAZ' departure from Bulgaria and Romania in 2010, and Bonniers leaving Latvia in 2009. As a result, the print media in these countries are now owned by local businesspeople. Unlike in Poland and Estonia, though, where national business elite started and grew media companies from the beginning, in Bulgaria, Latvia, and Romania, previously foreign-owned property was acquired by local businesses connected to nonmedia interests such as banks, oil, or as in the case of Romania - a mysterious off-shore company registered in Cyprus. ${ }^{11}$

Thus, ownership of media outlets in itself, further developing these companies, or even turning profits are not among the goals of the new owners. Rather, news media are being propped up by business interests, often selling newspapers at below production cost, to be used as political tools. ${ }^{12}$ The growing influence of local investors with unclear ownership and political ties has been reported in Slovakia as well. ${ }^{13}$ Beyond these three countries, Stetka points out a strong regional trend since 2006, with the "withdrawal of at least one international media player from a [Central Eastern European] country in place of a local owner" every year. ${ }^{14}$ 
While there is broad agreement that ownership matters for media freedom, how it matters in the postcommunist region has not been fully explored, with the few extant studies out there presenting mixed conclusions. ${ }^{15}$ With respect to concentration of ownership (either in foreign or local hands), while its impact is difficult to evaluate, Metykova and Cizarova provide evidence of editorial self-censorship due to oligopolistic control of media in the Czech Republic. ${ }^{16}$ Similarly, Balčytiene argues that "the critical levels" of media concentration in Lithuania, combined with no "established routines for how to cope with external pressures"17 has played a role in undermining media pluralism in the country. On the other hand, a Council of Europe report focusing on Croatia (and a select number of Western European countries) concludes that there are no direct links between media concentration and pluralism, and that diversity of news content is not compromised by concentration of ownership. ${ }^{18}$

Despite the normative agreement that private ownership is better for democracy and press freedom, Lauk points out that foreign (private) ownership of media does not necessarily have a positive impact on media in the postcommunist countries, arguing that there are "no indications that [foreign owners] have remarkably contributed to introducing similar professional values in the countries of their destination as in their home countries." ${ }^{19}$ Beachboard and Beachboard, however, point out that foreign financial investment in media can be beneficial for democratization, and cite the case of Finance in Slovenia, where investigative journalism was made possible due to foreign ownership. ${ }^{20}$ Similarly, Stetka finds that levels of foreign ownership correspond with the autonomy of investigative journalists in Bulgaria (low), Romania (medium), and the Czech Republic (high). ${ }^{21}$ Additionally, Szynol argues that the regional press in Poland was not affected by 
the political bias of their German owner, thus refuting the notion that foreign ownership has potential negative impact on press media content. ${ }^{22}$

Finally, in the countries that experienced a withdrawal of foreign media companies, change of ownership to a local "powerful figure with multiple non-media interests might act as a deterrent of investigative reporting about issues perceived as related to the owner's business or political activities." ${ }^{23}$ More generally, Ornebring surveying media owners, journalists, and politicians across the region concludes that when political and business elites assume that media are influential in public opinion and therefore try to control them for purposes of shaping political outcomes, the process leads to a weakness of investigative journalism, thus undermining the accountability watchdog function that media are expected to play in a democracy. ${ }^{24}$

\section{Media content}

While much scholarly interest has been focused on the legal aspects of media freedom and on the development of media systems across the postcommunist countries, ${ }^{25}$ one should observe that if media have an impact on voters and their behaviour, what ultimately matters should be the content of the news to which readers and viewers have access. Obviously legal freedoms and ownership of outlets affect news content and media bias, and there is an assumption that media affect political attitudes, behaviour and outcomes, and it is thus worth controlling. ${ }^{26}$ Yet, one cannot address the question of impact without also analysing the content of the news. Unfortunately, this aspect of the media has not been studied in depth in the postcommunist countries. In analysing news content there are several important aspects to consider: to what extent are specific topics and issues covered; what are the sources of journalistic evidence, and to what extent does 
reporting relies on diverse and independent sources; is there a bias or political slant in the stories; and what kind of information does the media emphasize?

One subject that has received a lot of study is media coverage of the European Union (in general), the accession of specific countries, and the European Parliamentary elections. There is long line of research on these issues in the western European countries, ${ }^{27}$ and since 2004/7 some more recent studies have included the new member states. ${ }^{28}$ Research on how media cover national election news in the postcommunist countries is much more limited and shows some mixed conclusions. Dobek-Ostrowska finds a strong bias among Polish broadcast media towards the ruling political parties, which she attributes to the left bias of the members of the regulatory body, National Broadcasting Council. ${ }^{29}$ Further, in their analysis of the print media in the 2005 elections, Dobek-Ostrowska and Lodzki found a greater plurality of opinions but a strong bias towards "parties and candidates who were leading in pre-election polls." ${ }^{30}$ On the other hand, Raycheva and Dimitrova argue that there is a reduction over time of political bias in the Bulgarian media, yet they also report widespread admission by journalists about incorrect reporting, false news, and accepting payments for positive political stories. ${ }^{31}$ Research also finds that despite decades of political liberalization, print media continues to rely primarily on elected officials to supply quotes and substantiate information for news stories. Milton found this to be the case in Bulgaria, Czech Republic, Poland, and Slovakia in the $1990 \mathrm{~s},{ }^{32}$ and Dimitrova and Kostadinova show that not much has changed a decade later. ${ }^{33}$ The reliance on government and public officials as news sources has serious implications for introducing political bias, limiting journalistic autonomy, and overall reducing pluralism in the media across the region. 
Another tendency in how the media cover political news is to enhance the latter's entertainment values by presenting political competition as a zero-sum game, so-called horse-race coverage. For example, Dimitrova and Postelnicu find widespread use of a strategic game frame in media coverage of the 2004 European Parliament elections in both Bulgaria and Romania. ${ }^{34}$ A more recent longitudinal study of news coverage in Bulgaria confirms that the strategic game frame dominates how news media portray political news, and that in fact this tendency has increased over time. ${ }^{35}$ Looking at the coverage of the 2005 Presidential elections in Poland, Tworzecki and Semetko also find that conflict framing, as opposed to more substantive policy-based coverage, is dominant in broadcast media in Poland, especially in the publically owned TV channel. ${ }^{36}$ The portrayal of political news as a game, a competition between (usually) two opponents comes at the expense of more detailed coverage, simplifies the substance of politics in many countries, and fails to provide a nuanced overview of the issues at hand. Further, such coverage of news can have negative implications for new democracies given that access to more substantive media stories is positively linked to issue consistency among Polish voters, ${ }^{37}$ and to levels of political engagement in Czech Republic, Hungary, and Poland. $^{38}$

Conclusions that both print and broadcast media in postcommunist countries provide limited non-substantive coverage of political news, are mirrored by an analysis of the extent to which media report the promises made by political parties during election campaigns. Analysing six Bulgarian newspapers, over seven elections in the period 19902009 , Kostadinova concludes that only a small fraction - around $12 \%$ of news stories include one or more of the election promises made by any of the political parties. ${ }^{39}$ 
Consequently, only a small share of election pledges are printed in the news, another indicator that media fail in their obligation to inform voters of the most salient issues of the campaigns. Further, in line with the dominance of strategic framing of news, and mirroring Dobek-Ostrowska's ${ }^{40}$ finding that Polish media favour governing parties and ignore the smaller ones, promises made by large parties, projected to win the most seats in the upcoming elections, were more likely to be reported by the Bulgarian news media than those of smaller parties. Lack of detailed and substantive content of news is not unique to political topics and is also reflected in how media cover economic news, and as Kostadinova and Dimitrova find, consistently over the 20 year period between 19902009 , media outlets overwhelmingly utilized episodic framing of economic news, i.e. omission of context and background information. ${ }^{41}$

\section{Implications and Proposed Research Agendas}

Quarter of a century after the end of communism, the EU EE countries are uniformly considered 'free' in terms of their political and civil liberties. Despite concerns about democratic deterioration in the region, it is obvious that there is a sharp distinction between this set of countries and other postcommunist states that are not members of the EU, nor are likely to join it. Yet, levels of media freedom and independence tell a more nuanced story. Based on general indicators, a number of EU EE countries appear to be 'stuck' in an unfinished transformation towards free and independent media, with some even experiencing deterioration. Further, there are significant differences within the EU EE group with respect to media freedom, both in terms of legal guarantees and ownership structures. 
Countries like Estonia and Poland, which have strong post-1990 traditions of domestic media ownership, as well as Czech Republic and Slovakia (although experiencing foreign ownership dominance) are also solidly among those countries with the greatest level of media freedom and independence. Countries whose media are considered partially free, like Bulgaria, Croatia, Hungary, and Romania, have low levels of foreign media ownership. Thus when conceptualizing media freedom broadly, as independence from government and political influences (measured for example in $\mathrm{FH}$ scores), the absence of foreign ownership seems to be synonymous with low levels of freedom. High levels of media freedom, however, cannot be explained by the presence of foreign capital. Intervening factors might have to do with country-specific traditions and practices. For example, in countries with weaker traditions in independent journalism, foreign investors might act as a safeguard against local owners' susceptibility to using media for political purposes. ${ }^{42}$ On the other hand, in countries where domestic conditions are favourable to pluralistic and independent media, foreign ownership (or the lack of it) does not seem to impact level of media freedom. Thus, while changes in foreign ownership of media in the EU EE is a phenomenon that cannot be ignored in the study of the region, it is hardly the only factor that helps scholars understand why some countries have achieved (or failed to do so) their status in terms of freedom of the media.

A related question concerns the common legacy of communism as a factor explaining outcomes in terms of media freedom and independence? As a group, the EU EE countries stand out with lower levels of media freedom when compared to the rest of the European Union, but higher levels than other countries with a communist past. All countries had tightly controlled propaganda machines, utilizing public media. Yet, 
despite this common legacy, the now EU EE exhibited both cross-national and temporal variation communist parties' control over media. ${ }^{43}$ For example, in Romania, which fit best the model of "co-ordinated, unequivocal and propagandistic media" 44 , censorship was much stronger than in Poland or (former) Yugoslavia. ${ }^{45}$ Poland even allowed satellite transmissions of TV programming from outside of the Soviet bloc, while television programming in Czechoslovakia and Bulgaria were closely integrated with, and relied heavily on, Soviet programs and shows. ${ }^{46}$

Additional differences involve practices in the journalistic profession during the communist period, and countries where journalists had greater level of (relative) independence and/or professionalization are among those with higher levels of media freedom in the post-communist period. For example, the Czech Republic stood out as a country where the journalistic professional there was highly institutionalized and adhered to professional standards, similar to those in the West. ${ }^{47}$ Further, in the Slovak part of the federation, journalists enjoyed some autonomy from centralized control, with independent Culture and Press offices, focusing on 'cultural' promotion yet contributing to a "Slovak-oriented content in the media."48 Finally, as Curry points out, journalism in Poland was characterized by "decreased level of fear and increased willingness to voice demands and opinions about the political situation." ${ }^{49}$ While the continuation of some of these traditions was interrupted by the transition when many older generation journalists were replaced by those untainted by a communist past, it would be difficult to argue that long-standing practices and norms would not continue to have an impact and to shape media independence. 
Further, given the sharp distinctions in levels of media freedom and independence between Central/Northern Eastern Europe on one hand, and its Southern flanks on the other, as well as the striking similarities between Southern Eastern Europe and EU SE, it is also likely that pre-communist legacies should be considered among the explanatory factors. The Czech Republic for example stands out with a strong tradition of very active independent and pluralistic media dating back to the period preceding World War II. ${ }^{50}$ Most of the other postcommunist countries on the other hand, share greater similarities in Southern Europe. As Hallin and Mancini explain, polarized pluralism exemplified by "a high degree of proximity between the media field and the political field, and a relative domination of the former by the latter", typical for Mediterranean countries such as Greece, Spain and Portugal, is most appropriate for characterizing media systems in some post-communist countries. ${ }^{51}$ Countries fitting this media system model share a number of historical and cultural characteristics, such as hierarchical societies centred on landed elites, strong Church influence, and "contested transition to liberal political and economic institutions". ${ }^{52}$

Finally, it is plausible that there is a complex relationship among legacies (pre-, communist, authoritarian, etc.) and other factors such as type of ownership and its concentration, journalistic traditions, economic conditions and crises, etc. that can explain variations in the media environment across countries. Thus, echoing Pop-Eleches (this volume), the diversity in the role of legacies (and other) factors across different areas is substantial and worth exploring. Finally, the data presented here also points to the weak utility of the term Eastern Europe (or postcommunist) when discussing media freedom and its relations to political and social outcomes, and media studies focused on the region 
would benefit from broader cross-regional and cross-country comparisons, a research strategy which has been successful in the study of political behaviour, as pointed out by Tucker (this volume).

The study of media in the postcommunist region provides scholars with the opportunity to engage in both theory-testing and theory-building endeavours. The disparate and often contradictory conclusions of media research on EU EE, highlighted in this paper, and echoed by Jerbil, Stetka, and Loveless ${ }^{53}$ suggest that applying media theories and expectations developed in established democracies to the study of other regions is of limited utility. Media studies in Western Europe developed as an academic field after both democratic and media institutions were consolidated, thus allowing research to explore the relationship between the two in a more stable context. In other world regions, but especially in the postcommunist one, interest in the relationship between media and democracy emerged along with democratization efforts, which further overlapped with attempts to establish free and independent media, amidst economic, and often statehood, transformations. Thus, this region allows scholars to not only test theories that emerged from the study of established democracies, but to also utilize the diversity within the postcommunist region to develop new theoretical insights about the complexity of the interactions between democratic and media transformations, in the context of other developments.

Thus, while disappointing for scholars of the region, the assessment that media studies are still underdeveloped in the postcommunist countries also highlights the opportunities presented to media and politics scholars. ${ }^{54}$ In particular, in addition to understanding variations in media freedom and environment, several gaps remain in the 
political communication research in the postcommunist countries. Why do media freedom and independence lag behind political and civil liberties, with a number of postcommunist democracies seemingly 'stuck' in the partly free category? What drives the recent deterioration in media freedom across a number of countries and regions, with the exception of EU WE? Did foreign media leave markets in some EU EE countries because the political environment was becoming less free, or did the media environment deteriorate after foreign companies departed? Or both? What is the impact of ownership and concentration patterns, especially on journalistic culture and professionalism, attitudes and behaviour in the newsrooms and editorial offices? How do media cover elections, and differences among political parties? Studies on coverage of European Parliament elections dominate the sub-field but much more is needed in terms of national elections. Finally, what is the impact of news stories content and bias on voters? Do ownership of the media, insufficiently detailed content of news, lack of contextualization, etc. have an impact on political behaviour and outcomes? Normatively, it seems that it should but systematic studies are lacking, which is especially troubling given the political drive to control media outlets in a number of countries. Thus, understanding variations in media freedom in the postcommunist countries, and its causes and consequences remains a potentially fruitful research area, where scholars could apply diverse research methodologies, such as surveys, in-depth interviews, content analyses, and experimental designs.

\footnotetext{
${ }^{1}$ The stylistic debate of whether 'media' is a singular or a plural noun is far from settled, with scholars, journalists, and editors espousing different perspectives. This article
} 
follows the latest Associated Press recommendations in using 'media' as a plural, based on one assumption and one exception. The assumption is that when the noun 'media' is used in the singular, this implies uniformity, a situation that has a number of negative connotations, esp. in the context of new democracies. Using media as a plural noun better highlights the diversity of print, broadcast, and social media outlets. The exception in the use of the plural 'media' is the following: where there are indications that media acts/functions in unison/agreement, the singular is used. In situations where the diversity and plurality of media are emphasized, the article uses the noun as plural. For more on this debate, see M. Perlman, "Media Rare: Revisiting Singular versus Plural," Columbia Journalism Review, February 27, 2012, available at http://www.cjr.org/language_corner/media_rare.php, accessed September 7, 2014.

${ }^{2}$ In the rest of the paper, these countries are referred to as EU EE.

${ }^{3}$ Data are available from each respective organization's website, and were accessed by the author between November 2013 and May 2014.

${ }^{4}$ For the purposes of this paper, in addition to EU EE, countries are grouped in the following categories. EU WE (Austria, Belgium, Denmark, Finland, France, Germany, Ireland, Luxembourg, Netherlands, Sweden, United Kingdom); EU SE: (Cyprus, Greece, Italy, Malta, Portugal, Spain); EU 17: (EU WE and EU SE); Western Balkans: Albania, Bosnia-Herzegovina, Macedonia, Montenegro, Serbia; and Post-Soviet: Armenia, Azerbaijan, Belarus, Georgia, Kazakhstan, Kyrgyzstan, Moldova, Russia, Tajikistan, Turkmenistan, Ukraine, Uzbekistan.

${ }^{5}$ For example, S. Djankov, C. McLiesh, T. Nenova, and A. Shleifer, "Who Owns the Media?," Journal of Law and Economics 46(2003): 341. 
${ }^{6}$ For example, P. Leeson, "Media Freedom, Political Knowledge, and Participation," Journal of Economic Perspectives 22(2008): 155.

${ }^{7}$ Reports are available at http://mde.politics.ox.ac.uk/ and http://europe.ifj.org/en/articles/media-power-in-europe-the-big-picture-of-ownership, respectively. Accessed on Nov 20, 2013.

${ }^{8}$ V. Stetka, The Czech Republic (Country report for the ERC-funded project on Media and Democracy in Central Eastern Europe, 2012a), at http://mde.politics.ox.ac.uk/images/stories/bulgaria_mdcee_rev3_2011.pdf accessed November 26, 2013.

${ }^{9}$ A. Szynol, "Polish Media 22 Years After Socio-Political Breakthrough-The Road to Professionalization and Democratization," Journalism and Mass Communication 2(2012): 329; E. Hume, "Caught in the Middle: Central and Eastern European Journalism at a Crossroads," Center for International Media Assistance (2011).

${ }^{10}$ M. Tyrmand, “Poland's Coming Recession”, Forces Opinion, December 1, 2014, accessed February 6, 2015.

${ }^{11}$ Although a direct link between media ownership in Romania and Russian interests is difficult to substantiate, it is well documented that Gazprom has diversified its holdings in Europe to include media companies (A. Heinrich, "Gazprom's Expansion Strategy in Europe and the Liberalization of EU Energy Markets," Russian Analytical Digest 34(2008): 8). Further, Russia's state-controlled oil company has nine subsidiaries registered in Cyprus (K. Dawisha, Putin's Kleptocracy: Who Owns Russia (Simon \& Schuster, 2014), a popular tax haven in the region, including among Romanian businessmen (M. Preoteasa, "Romania," in Media Ownership and Its Impact on Media 
Independence and Pluralism, ed. B. Petkovid, 403-424 (Ljubljana: Peace Institute, 2004);

M. Preoteasa, "Regulation, policy and independence of television in Romania," in Television Across Europe: Regulation, Policy and Independence. Monitoring Reports, ed. M. Dragomir, 1231-1314 (Budapest: Open Society Institute, 2005). Thus, it is plausible that there is a connection between Romanian oligarchs and Russian oil money.

${ }^{12}$ H. Örnebring, "Clientelism, Elites, and the Media in Central and Eastern Europe," International Journal of Press / Politics 17(2012b): 497.

${ }^{13}$ V. Stetka, Slovakia (Ccountry report for the ERC-funded project on Media and Democracy in Central Eastern Europe, 2012b), at http://mde.politics.ox.ac.uk/images/stories/documents/slovakia\%20report_updated_aug12 final.pdf, accessed November 26, 2013.

${ }^{14}$ V. Stetka, "From Multinationals to Business Tycoons: Media Ownership and Journalistic Autonomy in Central and Eastern Europe," The International Journal of Press/Politics, 17(2012c): 433, p. 439. In addition to these three cases, foreign investors left Slovakia in 2010 and the Czech Republic and Hungary in 2013, according to V. Stetka, Media Ownership and Commercial Pressure (Pillar One-Final Report, 2013) at http://mde.politics.ox.ac.uk/images/Final_reports/stetka_2013_final\%20report_posted.pd f, accessed November 26, 2013.

${ }^{15}$ While the question of why foreign companies choose to invest in media enterprises in the EU EE is tangential to this study, two primary factors should be highlighted. Business investment, the desire to make profits, and to expand markets was certainly among the motivations for such investment. Further, print and broadcast enterprises in the postcommunist countries were in need of updates and modernization, and the funds for 
such were difficult to come by through privatization to local business interests (for additional discussion of the motivations of foreign investors in EU EE media market, see for example A. Wyka, "Media Privatization and the Spread of Foreign Ownership in East Central Europe," unpublished manuscript, 2011). A second factor that drove investment in the EU EE media industries, especially the geographic distribution of the former, to some extent had to do with historical and regional cross-country ties. Thus it is hardly a coincidence that Swedish media conglomerates had a strong interest in the Baltics, and that Germany's expanded to Central and Southern Europe.

${ }^{16}$ M. Metykova and L. Cisarova, "Challenges of Media Concentration: The Case of Regional Press Ownership in the Czech Republic," in Media in the Enlarged Europe, ed. A. Charles, 169-176 (Bristol, United Kingdom: Intellect, 2009)

${ }^{17}$ A. Balčytienè, “Mixed Professional Values in a Small and Highly Blurred Media Environment," in The Media for Democracy Monitor: A Cross National Study of Leading News Media, eds. J. Trappel, H. Nieminen, and L. Nord, 175-203 (Goteborg, Sweden: Nordicom, 2011), p. 199.

${ }^{18}$ Council of Europe, The assessment of content diversity in newspapers and television in the context of increasing trends towards concentration of media markets (Final report on the study commissioned to Mr D. WARD by the MC-S-MD, 2006), at http://www.coe.int/t/dghl/standardsetting/media/Doc/MC-SMD\%282006\%29001_en.pdf, accessed October 3, 2013.

${ }^{19}$ E. Lauk, 2009, "Reflections on Changing Patterns of Journalism in the New EU Countries," Journalism Studies 10(2009): 69-84, p. 76 
${ }^{20}$ M. Beachboard and J. Beachboard, "Implications of Foreign Ownership on Journalistic Quality in a Postcommunist Society: The Case of Finance," Informing Science Journal 9(2006): 143.

${ }^{21}$ V. Stetka, Media Ownership and Commercial Pressure" (Pillar One-Final Report, 2013) at

http://mde.politics.ox.ac.uk/images/Final_reports/stetka 2013 final\%20report posted.pd f, accessed November 26, 2013.

${ }^{22}$ A. Szynol, “15 Years of Passauer Neue Presse (Polskapresse) and Orkla Media Presence on Polish Regional Press Market," in Comparing Media Systems in Central Europe. Between commercialization and politicization, eds. M. Głowacki and B. Dobek Ostrowska, 135-148 (Wroclaw, Poland: University of Wroclaw, 2008).

${ }^{23}$ V. Stetka, 2012c, p. 448.

${ }^{24}$ H. Örnebring, "Clientelism, Elites, and the Media in Central and Eastern Europe," International Journal of Press/Politics 17(2012b): 497.

${ }^{25}$ For example, see P. Bajomi-Lázár and I. Hegedus, eds. Media and Politics (Budapest, Hungary: Uj Mandatum Könyvkiado, 2001); P. O’Neil, ed. Communicating Democracy: The Media and Political Transitions (Boulder, CO: Lynne Rienner, 1998); D. Paletz, K. Jakubowicz, and P. Novosel, eds. Glasnost and After: media and change in Central and Eastern Europe (Creskill, NJ: Hampton Press, 1995); D. Paletz and K. Jakubowicz, Business as Usual. Continuity and Change in Central and Eastern Europe (Cresskill NJ: Hampton Press, 2003); M. Sükösd and P. Bajomi-Lázár, eds. Reinventing Media: media policy reform in East-Central Europe (Budapest, Hungary: Central European University Press, 2003). 
${ }^{26}$ For the perspective that political elites aim to control the media not only for political gains, but also as a form of patronage, and to extract further economic resources, see P. Bajomi-Lazar, "The Party Colonisation of the Media: The Case of Hungary," East European Politics and Societies 27(2013): 69.

${ }^{27}$ For example, see D. Hutchinson, "The European Union and the Press" in Media in the Enlarged Europe. Politics, Policy and Industry, ed. A. Charles, 53-60 (Bristol-Chicago: Intellect, 2009); L. Kaid, ed. The EU Expansion: Communicating Shared Sovereignty in the Parliamentary Elections (New York: Peter Lang, 2008); J. Strömbäck and L. Kaid, eds. Handbook of election news coverage around the world (London, United Kingdom: Routledge, 2008);

${ }^{28}$ M. Maier, J. Strömbäck, and L. Kaid, eds. Political Communication in European Parliamentary Elections. Campaign Strategies, Media Coverage, and Campaign Effects in European Parliamentary Elections (Farnham-Burlington: Ashgate, 2011).

${ }^{29}$ B. Dobek-Ostrowska, "Political parallelism or political bias? Consequences for the quality of democracy in Poland" in Making Democracy in 20 Years. Media and Politics in Central and Eastern Europe, eds. B. Dobek-Ostrowska and M. Głowacki, 193-212 (Wrozlaw: University of Wrozlaw, 2011).

${ }^{30}$ B. Dobek-Ostrowska and B. Lódzki, "Election news coverage in Poland," in Handbook of election news coverage around the world, eds. J. Strömbäck and L. Kaid, 226-245 (London, United Kingdom: Routledge, 2008), p. 240.

${ }^{31}$ L. Raycheva and D. Dimitrova, "Election news coverage in Bulgaria" in Handbook of election news coverage around the world, eds. J. Strömbäck and L. Kaid, 341-356 (London: United Kingdom: Routledge, 2008) 
${ }^{32}$ A. Milton, "News Media Reform in Eastern Europe: a cross-national perspective," in Post-Communism and Media in Eastern Europe, ed. P. O’Neil, 7-23 (London: Frank Cass, 1997).

${ }^{33}$ D. Dimitrova and P. Kostadinova, "Use of Sources in Newspaper Coverage of the 2009 Bulgarian Parliamentary Elections," Central European Journal of Communication 1(2012): 81 .

${ }^{34}$ D. Dimitrova and M. Postelnicu, "Coverage of the Election in Candidate Countries: A View from Bulgaria and Romania," in The EU Expansion: Communicating Shared Sovereignty in the Parliamentary Elections, ed. L. Kaid, 175-188 (New York: Peter Lang, 2008).

${ }^{35}$ D. Dimitrova and P. Kostadinova, "Identifying Antecedents of the Strategic Game Frame: A Longitudinal Analysis," Journalism and Mass Communication Quarterly 90(2013): 75 .

${ }^{36}$ H. Tworzecki and H. Semetko, "Media Uses and Effects in New Democracies: The Case of Poland's 2005 Parliamentary and Presidential Elections," The International Journal of Press/Politics 15(2010): 155.

${ }^{37}$ H. Tworzecki and H. Semetko, "Media Uses and Effects in New Democracies: The Case of Poland's 2005 Parliamentary and Presidential Elections," The International Journal of Press/Politics 15(2010): 155.

${ }^{38}$ H. Tworzecki and H. Semetko, "Media Use and Political Engagement in Three New Democracies: Malaise vs. Mobilization in the Czech Republic, Hungary, and Poland," The International Journal of Press/Politics 17(2012): 407. 
${ }^{39}$ P. Kostadinova, "Media portrayal of election promises: the case of Bulgaria, 19902009” (paper presented at the annual meeting of the American Political Science Association, Washington, DC, August 28-31, 2014).

${ }^{40}$ B. Dobek-Ostrowska, 2011.

${ }^{41}$ P. Kostadinova and D. Dimitrova, "Communicating Policy Change: Media Framing of Economic News in Postcommunist Bulgaria," European Journal of Communication 27(2012): 171 .

${ }^{42}$ Hungary is the obvious exception here, as it does have a strong tradition in investigative journalism (Spiros 2013), which however was heavily disrupted by the restrictive media laws passed during Prime Minister Orban's first term of office. Thus, more recent authoritarian tendencies seem to have an impact similar to a lack of longstanding traditions.

${ }^{43}$ For an extensive overview on variations in press freedom under communism, see for example D. Shanor, "Press Freedom in the Communist World," in Comparing Media Systems, eds. J. Martin and A. Chaudhary, 327-340 (Longman, 1983).

${ }^{44}$ C. Sparks (with Anna Reading) Communism, Capitalism and the Mass Media (London: Sage, 1998), p. 56.

${ }^{45}$ Alina Mungiu-Pippidi, chapter 3, "Freedom without impartiality. The vicious circle of media capture" 33-47.

${ }^{46}$ Sparks, Communism, Capitalism and the Mass Media

${ }^{47}$ Jan Jirak and Barbara Kopplova, chapter 12, "Two decades of free media in the Czech Republic: So What? Remarks on the discourse of post-1989 media transformation" 183194. 
${ }^{48}$ Owen V. Johnson, chapter 10, "Entertaining the people, serving the elites: Slovak mass media since 1989”, 149-165. P. 153.

${ }^{49}$ J. L. Curry Poland's Journalists: professionalism and politics (Cambridge: Cambridge University Press, 2011), p 33.

${ }^{50}$ E. Hume, "Caught in the Middle: Central and Eastern European Journalism at a Crossroads"

${ }^{51}$ D. Hallin and P. Mancini, "Comparing Media Systems between Eastern and Western Europe," in Media Transformation in the post-communist world: Eastern Europe's Tortured Path to Change, eds. P. Gross and K. Jakubowicz, 15-32 (Lexington Books, 2013), p 19. Hallin and Mancini, however, are quick to point that Italy's media system is different from that of the remaining Mediterranean countries in the EU.

${ }^{52}$ Hallin and Mancini, p. 19.

${ }^{53}$ N. Jerbil, V. Stetka, and M. Loveless Media and Democratisation: What is Known about the Role of Mass Media in Transitions to Democracy (Reuters Institute to the Study of Journalism Report, 2013) at https://reutersinstitute.politics.ox.ac.uk/sites/default/files/Media\%20and\%20Democratisat ion.pdf, accessed Sept 10, 2014.

${ }^{54}$ For an additional overview of the state of research of media in postcommunist countries, see Jerbil et al 2013. 
Table 1. Rankings in press freedom and independent media across 11 postcommunist countries, and select regions.

\begin{tabular}{|c|c|c|c|c|c|c|}
\hline Country & $\begin{array}{l}\text { FH Freedom of } \\
\text { the Press }(2014)\end{array}$ & Designation & Country/Region & $\begin{array}{l}\text { Nations in Transit } \\
\text { Independent } \\
\text { Media (2014) }\end{array}$ & Country/Region & $\begin{array}{l}\text { RWB Press } \\
\text { Freedom (2014) }\end{array}$ \\
\hline Estonia & 16 & $\mathrm{~F}(=)$ & Estonia & $1.5(=)$ & Estonia & $9.63(-)$ \\
\hline Czech Republic & 20 & $\mathrm{~F}(=)$ & Latvia & $2(-)$ & Czech Republic & $10.07(+)$ \\
\hline Slovakia & 23 & $\mathrm{~F}(=)$ & Lithuania & $2.25(-)$ & Poland & $11.03(+)$ \\
\hline Lithuania & 24 & $\mathrm{~F}(=)$ & Slovenia & $2.25(=)$ & Slovakia & $11.39(+)$ \\
\hline Slovenia & 24 & $\mathrm{~F}(=)$ & Poland & $2.5(=)$ & Lithuania & $19.2(+)$ \\
\hline Latvia & 27 & $\mathrm{~F}(=)$ & Czech Republic & $2.75(-)$ & Slovenia & $20.38(+)$ \\
\hline Poland & 27 & $\mathrm{~F}(=)$ & Slovakia & $2.75(=)$ & Latvia & $21.1(+)$ \\
\hline Hungary & 35 & PF (-) & Hungary & $3.5(=)$ & Romania & $23.48(-)$ \\
\hline Bulgaria & 39 & PF (-) & Bulgaria & $4(-)$ & Hungary & $26.73(-)$ \\
\hline Croatia & 40 & $\mathrm{PF}(=)$ & Croatia & $4(=)$ & Croatia & $26.82(-)$ \\
\hline Romania & 41 & $\mathrm{PF}(=)$ & Romania & $4.25(=)$ & Bulgaria & $31.42(-)$ \\
\hline EU EE & 29 & $\mathrm{~F}(-)$ & EE EU & $2.89(-)$ & EU EE & $19.20(+)$ \\
\hline Western Balkans & 46 & PF (-) & Western Balkans & $4.4(-)$ & Western Balkans & $30.61(-)$ \\
\hline Post-Soviet & 75 & $\mathrm{NF}(=)$ & Post-Soviet & $5.98(=)$ & Post-Soviet & $43.96(-)$ \\
\hline EU 17 & 20 & $\mathrm{~F}(-)$ & & & EU17 & $14.91(+)$ \\
\hline EU WE & 15 & $\mathrm{~F}(=)$ & & & EU WE & $11.06(+)$ \\
\hline EU SU & 29 & $\mathrm{~F}(-)$ & & & EU SU & $21.96(=)$ \\
\hline
\end{tabular}

Notes: (1) The lists of countries belonging to each group, EU EE, EU 17, EU WE, EU SU, Western Balkans, and Post-Soviet, appear in endnote 4. (2) The FH Freedom of the Press and RWB Press Freedom indexes each range from 0 to 100, while the Nations in Transit Independent Media measure is scaled from 1 to 7. In all three instances, lower scores indicate greater levels of media freedom. (3) The designation column reflects a categorical measure of media freedom, based on the FH Freedom of the Press index scores; F: Free, PF: Partly Free, and NF: Not Free. (4) The signs in parentheses indicate the direction of chance (if any) for each index since 2010: '=' no change; '- 'worsening of this indicator, and '+' improvement in score. 
Figure 1. Freedom House Freedom of the Press Scores, 1993-2013

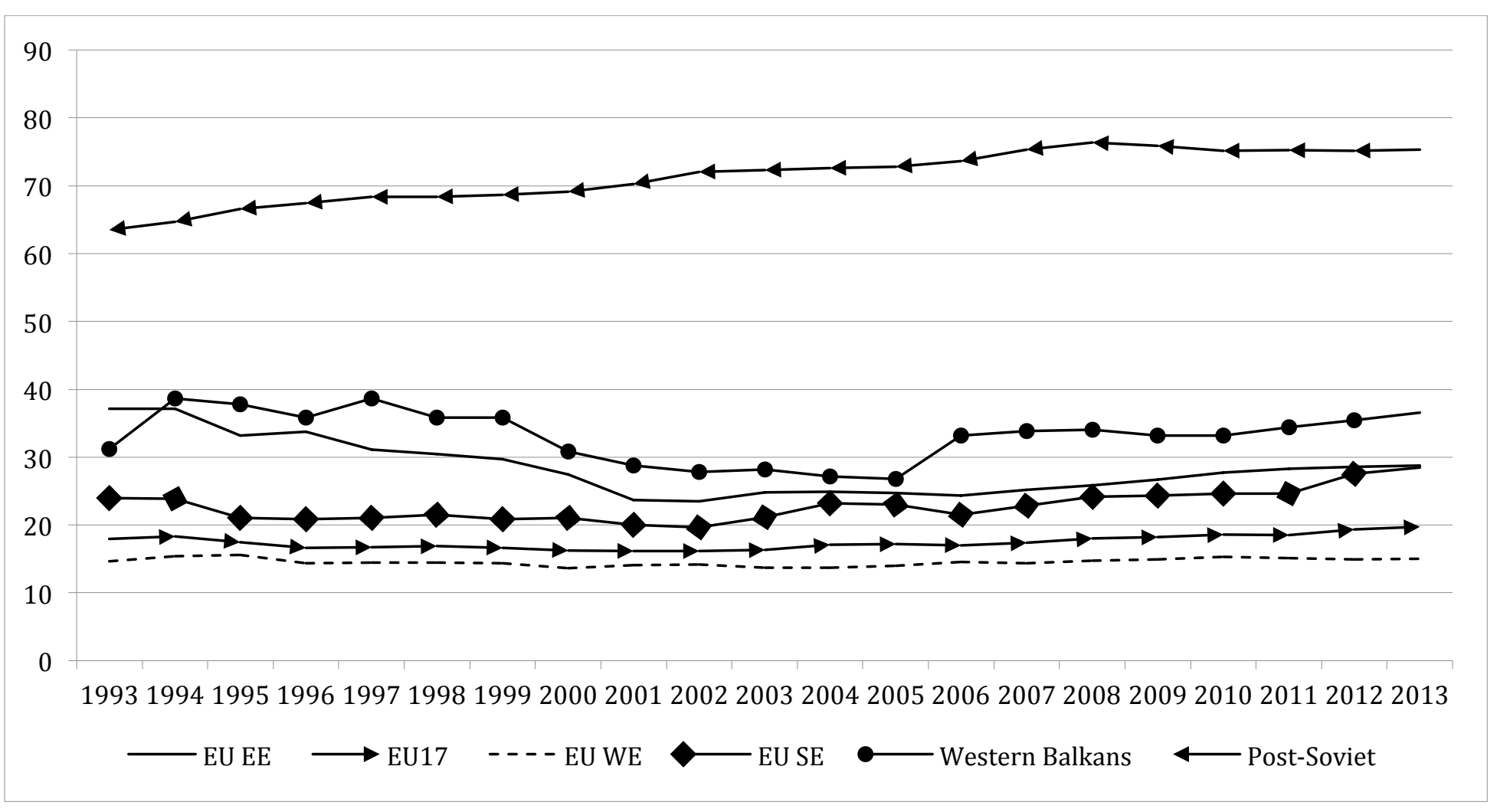

Note: The lists of countries belonging to each group, EU EE, EU 17, EU WE, EU SU, Western Balkans, and Post-Soviet, are in endnote 4 